\title{
BUILDING RELIGIOUS HARMONY AMONG YOUNG CHILDREN: EXPERIENCE FROM INDONESIAN ELEMENTARY SCHOOL
}

\author{
DJUNAWIR SYAFAR *, MUJAHID DAMOPOLII \\ Institut Agama Islam Negeri Sultan Amai Gorontalo
}

\section{Abstract}

This article is a study of the harmonization of Islam, Christianity, and Buddhism in SD Negeri (State Elementary School) 46 Hulontalangi, Gorontalo City. The school plays important roles because it is the first state school in Gorontalo City that develops and implements the concepts of religious harmony and pluralism in a school environment. This research is a qualitative study which uses three data collection methods, namely: (1) observation, (2) in-depth interviews, (3) documentation. The findings show that the implementation of religious harmony is manifested in religious, social, and cultural cooperation. The cooperation has become a habit that affects the outlook and actions of all school members in their daily lives. The habit is inseparable from the role of teachers, parents, students, and all school residents who become teachers and learners from their environment. It results in harmony cooperation, namely cooperation that is not only in the form of ideas and words but also affects the social environment. Thus, what has been implemented at this institution can be an alternative solution for schools or other institutions on how religious pluralism can be facilitated and placed in the right position and needs.

Artikel ini merupakan studi tentang harmonisasi Islam, Kristen, dan Buddha yang ada di SD Negeri 46 Hulontalangi Kota Goronta-

\footnotetext{
* Corresponding author: Jl. Gelatik, Kota Timur, Kota Gorontalo, Indonesia.

E-mail: djunawir_syafar@iaingorontalo.ac.id. 
lo. Peran Sekolah ini menjadi penting, karena merupakan sekolah dasar negeri pertama di Kota Gorontalo yang mengembangkan dan menerapkan konsep harmonisasi dan pluralisme agama yang ada dalam satu lingkungan sekolah. Penelitian ini adalah penelitian kualitatif yang dalam pengumpulan datanya menggunakan tiga metode, yaitu: (1) observasi (observation), (2) wawancara mendalam (in-dept interview), (3) dokumentasi (study of documents). Penelitian ini menunjukkan bahwa, implementasi harmonisai agama terwujud dalam kerjasama keagamaan, sosial, dan juga budaya. Bentuk kerjasama ini menjadi sebuah pembiasaan yang berdampak pada cara pandang dan tindakan selurub warga sekolah dalam keseharian. Pembiasaan tersebut tidak lepas dari peran guru, orang tua murid, peserta didik, dan selurub warga sekolab yang menjadi pengajar sekaligus pembelajar dari lingkungannya. Hal ini melahirkan kerjasama harmoni, yakni kerjasama yang tidak hanya dalam bentuk ide dan kata-kata, tetapi berdampak pada lingkungan sosialnya. Dengan demikian, apa yang telah diterapkan di lembaga ini dapat menjadi solusi alternatif bagi sekolah atau lembaga lain, tentang bagaimana pluralisme agama dapat difasiliatasi dan didudukkan pada posisi yang tepat dan sesuai dengan kebutuhan.

Keywords: Buddhism; children; Christian; education; elementary school; Islam; religious harmony.

\section{Introduction}

Inter-religion relations experience dimensions of plurality in various countries, including in Indonesia, and become an urgent problem that requires solutions from all components of society to make such dimensions run in a balanced and harmonious manner. Addressing the problem is urgent because the problem is very complicated since understanding plurality and the dimensions of religions itself are not only related to theological teaching, but also related to other social factors that influence each another. One of the salient examples dealing with this issue is a 
factor related to socio-political issues. When religion has arrived at reality or society, then it will come into contact with the reality of society itself, which is also complex. This is where the role of various components of society, including educational institutions, is needed, especially in terms of how these differences contribute to community development instead of social obstacles.

The relation between religious communities in a plural society always fluctuates ups and downs and not always in harmony. Although, each doctrine or religious teaching teaches about harmony, peace, mutual respect, upholding the principle of togetherness, and other sets of noble values, but in reality the religious doctrine, the decision of the ulema council, the decision of the council meeting, or the results of the ideal world-class church council agreement do not guarantee the realization of overall peace (Abdullah 2005, 36).

One of the most significant conflicts involving the dimension of the religious community was what happened in Maluku and Poso from 1999 to 2002, which claimed up to 8,000 people (Suseno 2005, 12). This issue is proof that religion becomes complex when it meets reality in society. Religion becomes a factor and context which faces problems of democratic transition in either the center or the middle of the regions.. This condition has also influenced the tensions of the community, which then causes ethnic and religious conflicts with political content.

The problems of religion in Indonesia show that there is a strong power relation of each social-religious authority. This power can transform in the form of ideological channels, institutions, systems, and other social networks. This reason depicts why interreligious relations are the center of issues that are widely used by individuals and groups in any case to show the existence of power and existence in society. On the one hand, religion continues to experience progress and development along 
with the development of society; on the other hand, religion is still experiencing tension, which has a significant impact on society. This idea has become an essential part of religious pluralism discourse, including the education world seeking to find the right models, policies, and approaches to bridge.

The role of education in the discourse of interfaith relations has a central and strategic position. Educational institutions from early childhood education level to higher education level have the authority on how to build a paradigm, habituation, preparation of social tools, and the implementation phase within the community. These aspects are the ones that should facilitate how to build a model or way to socialize in a plural environment.

This article aims at explaining how the harmonization practice of Islam, Christianity, and Buddhism exists at SD Negeri (State Elementary School) 46 Hulontalangi, Gorontalo City. Several questions arise regarding why the school becomes the sample, the interesting part from its implementation, and its contributions to social life. The answers to questions will be explained in the discussion section, such as the form of harmony between religious communities in SD Negeri 46 Hulontalangi Gorontalo City. In this study, researchers used qualitative research using participatory observation methods, documentation, and in-depth interviews to obtain in depth information and data (Sugiyono 2008, 227-31).

This study reveals different findings from previous studies. The one conducted by Al Makin shows that the archipelago (Indonesia) offers a religious pluralism form with the terms, conditions, and socio-historical nature of Indonesian society that are not static. Instead, it is highly adaptive to the conditions of the past, present, and future (Makin 2016, 28-29). Meanwhile, the results of this study further explain how the workings of 
religions offer their respective approaches when meeting in a social environment, for example in education as a harmony approach implemented in SD Negeri 46 Hulontalangi Gorontalo City through religious, social, and cultural cooperation.

A religious harmony is a form of human balance in carrying out the function of religion in daily life. It does not merely become a momentum-based goal because humans must continue to establish harmonious relations with their environment, and this is the goal of religion itself (Ali 1976). Religion is present for human life, including to explain the relationship between God, man, and nature.

Understanding the construction of religious pluralism in this school uses the Nurcholis Madjid humanist pluralism theory, which is based on aspects of humanity and inclusiveness (openness) (Madjid 2001, 46). Firstly, humanity rests on the view that religion is revealed to humankind, which serves for their salvation. For example, Islam, as the mission of the Prophet $\mathrm{Mu}-$ hammad, serves to bring mercy to the universe (rabmatan lil 'álaminn). Religion is not understood as an abstract formula of value beliefs, but it is integrated and expresses itself in real life of its adherents (Madjid 2005, 582).

Secondly, inclusiveness or openness refers to a condition where each religion must uphold mutual respect and tolerance. Humans do not live alone, but live side by side with various adherents of different religions in an area, city, and even in one village.

Nurcholish Madjid's view above is closely related to the context of Indonesian society's life, which is very diverse, as illustrated in this school. The relationship between religious communities in this school is quite interesting wherein daily interactions, starting from educators, students, parents, and all elements of the institution, do not place religion as distance. They 
believe that someone who has a good understanding of religion should increasingly show a tolerant attitude. Religion is a guide of life, and every religion teaches the values of goodness, including mutual respect, either with other people or with followers of other religions. This view must be manifested in daily actions, such as how to communicate, interact, and act. Such action can build good cooperation between each adherent of religion and erode prejudice for each adherent of religion.

\section{Locus of Research and Construction of Religious Pluralism}

As the capital city of Gorontalo Province, Gorontalo city is identical to the Muslim community due to the majority of the population. Even so, this city surprisingly has its privileges where in the midst of a population that is predominantly Mus$\mathrm{lim}$, there is a plurality dimension, namely the existence of Christian, Hindu, and Buddhist communities as a core part of society. In addition to the general public knowing Gorontalo society as a Muslim society, it turns out that there is also a dimension of plurality in the daily lives of its citizens.

The composition of Gorontalo City community is based on religions that consist of Islam with 193,173 people, Protestant with 5,100 people, Catholics with 2,700 people, Hindu with 256 people, and Buddhist with 953 people (Dokumen Resmi 2017). Of this amount, the plurality is not measured based on quantity because the total population of Gorontalo City is not large in number, so the existence and role of other religions become an important consideration and dimension in building social relations in daily life. The above social conditions become the main reason why SD Negeri 46 Hulontalangi, Gorontalo City, with its diverse student compositions, is selected as the research setting. Judging from the total number of students, this school has a religious representation of 331 Muslims, 67 Christians, and 42 Buddhists (Dokumen Sekolah 2017, 2). 
The school, which was established in 1947, is located in Tenda village, Hulontalangi District, Gorontalo City (Dokumen Sekolah 2017, 15). Geographically, the position of this school is right in a relatively heterogeneous residential area, which is not far from several worship places. The location has influenced social construction in this school because it causes the meeting of different religious entities for students choosing education in this school. This factor requires the school to be able to manage and provide educational services that are appropriate to the needs of its students.

Besides, this school is the first state elementary school and the only school in Gorontalo City that has implemented the real practice of harmonization between religious communities through its school policy and program system. There are several school programs that are related to harmonization between religious communities. Firstly, each of the religions, namely Islam, Christianity, and Buddhism, have been facilitated with its respective teaching staff. Secondly, the three religions are given space to actualize religious practices in schools every day, such as the existence of worship and religious formation for Christians, and Buddhists and the implementation of prayer or other religious formation for Muslims. Thirdly, the program that has more value aiming at building harmony and cooperation among religious communities is to facilitate the celebration of religious holidays for Islam, Christianity and Buddhism. This effort has become a real practice of the realization of harmonization in schools and become a distinctive policy feature among other public elementary schools in the Gorontalo City area.

\section{From Cooperation and Habituation Towards Harmony}

Before discussing further on the process of harmony creation between religious communities, it is crucial to understand in advance how the dimension of the religion history itself. 
The historical journey of religion follows the course of human life. Anthropologists have argued that from the beginning to the present time, there has never been a society that lives without religion, even though the religions embraced are different. Even an elementary society, which is often called an illiterate, primitive, or aboriginal society, may have religion embraced. Various terms are introduced and used to refer to religion, such as animism, dynamism, fetishism, and totemism. All of these terms show that from the beginning, humans have believed in the existence of specific non-sensory forces that are believed to influence and determine human life (Djam'annuri 2002, 6).

In Indonesia, before prominent religions such as Hinduism, Buddhism, Islam, Christianity, and Confucianism came, the community had its belief system as a local religion at that time. This fact shows that the dimension of plurality in people's lives is a necessity because the process of finding religion as a belief follows the process of human life. Djam'annuri explains that the history of religion is as old as human history because religion is always present in human life no matter how simple it is (Djam'annuri 2002).

The above view is closely related to today's community life where one of the issues faced by the community is how to position the encounters of these religions in real life of the community while at the same time bringing the dimension of difference to bring positive values for inter-religious life.

In the state context, Indonesia has reached an agreement or consensus in bridging the issue of religious plurality. Pancasila is the basis of views to bridge the life of religious people so that a meeting point as a social bridge exists within the differences of each religion. The position of Pancasila as the primary value of the state has a fundamental role in various policies concerning the structure of people's lives. This fundamental value becomes a 
thinking framework and content of the certain policy, including in the laws of our national education system. One concrete form of the policy is listed in Article 13 of the National Education System Law, namely, "students have the right to obtain religious education by their respective religions" (Undang-Undang Sistem Pendidikan Nasional 2008, 10).

From this point, it is obvious that the issues related to religious plurality in education have been legally recognized so that the rights and obligations in fulfilling the needs of religious education must have a clear and appropriate position. This is not only because of its formality but at the same time, becomes a core need for community development in obtaining rights and obligations as citizens.

If we look more specifically at the practice of harmonization between Islam, Christianity, and Buddhism in SD Negeri 46 Hulontalangi Gorontalo City, there are unusual characteristics that are fundamental. The term fundamental meant here is in the sense that the process is built from the social construction that exists in this school. The fact that the school has students who have different religions requires it to accommodate the needs that can be met under these conditions. Meanwhile, the process does not happen in simplyy, but it happens through fundamental stages, namely from a cooperation process, then leads to a habituation process that results in harmonization. As explained by Ms. Sintje Akadji:

That harmonization process between religious people in this school happens through stages that are not instant. However, it happens through the process of adaptation to the process of collaboration, which is called habituation and harmony

The habituation is carried out, for example, through daily examples between educators in the school dealing with how to communicate, socialize, work together, and other things that can 
form the core of the harmonization goals among religious communities within the school environment. What is exemplified becomes the value of education taught to all students and school residents so that over time, all school members become accustomed to the context of plurality in their social environment.

That is the stage of how cooperation turns into habituation to harmony so that relationships built around the school have a social impact on society. The togetherness and cooperation built are not only felt in the school environment but also awakened in the community. For example, the collaboration among teachers, students, and parents occurs during religious holidays not only at school and community but also in daily life, and each has its way of maintaining the harmonization such as visiting each other, helping each other when the community members hold specific programs, and other forms of social cooperation.

It is interesting to understand that the way all school members do the habituation becomes daily behavior. Meanwhile, the driving force of harmonization between religious groups in this school is collective, which is carried out by all school members. This method is considered appropriate because the core of the peace movement is all components of the school community, not authoritatively from the principal or from the teaching staff. The next challenge is identifying the position of the government and the contributions of the government in this matter. In this regard, the government's position is not a determinant, but rather a partner and authority provider related to various policies needed. The government is the school's partner to communicates whenever there are matters related to the duties and authority of the government.

The conditions help to strengthen policies that support the form of harmony between religious communities in the school. If the government determines the whole school agenda, so what is desired by the government may not necessarily be right on the 
targets or needs because the school community is the one who knows more about the problems at school. It can be said that this policy is appropriate to answer the problem because it has built good cooperation at the internal level of school and the government to other social, religious institutions.

\section{Harmonization Forms of Islam, Christianity, and Buddhism}

Harmonization is a joint movement in differences that produces benefits, and this is to bear in mind that differences are proven to be useful with the accompaniment of tolerance (Abdullah 2005, 34). There is a value in differences that becomes a meeting point for achieving a common benefit. This means that differences will be a contributor to community development when they are placed in the right position. For example, the fact that three major religions that meet in one reality in this school are a value that becomes a source of learning on how each religion adheres to other religions in the context of social relations.

The tension that often occurs between one religious group with other groups cannot be separated from the fact that belief understanding only stops as the belief that does not try to further apprehend other dimensions more broadly, such as when religion meets other religions in social reality. A community will always encounter with other identities wherever and whenever. For this reason, it is necessary to have shared values as a meeting point to achieve harmony. Humans need harmony because their existence as religious creatures does not always work in peace and harmony, but they are always accompanied by social problems that cannot be separated from religion. To avoid conflicts that have negative impacts on socio-humanitarian issues, harmonization becomes the value needed as a counterweight connecting these differences.

The harmony between religious communities in SD Negeri 46 Hulontalangi Gorontalo City, unites and forms in "three 
forms of harmony" namely: (1) religious harmony, (2) social harmony, and (3) cultural harmony.

First, religious harmony refers to an act of cooperation involving other religions in religious work. The religious harmony in this model is not an activity interfering either theological or religious normativity of other religions; it rather religious activity in the area of praxis or social relations. An example of this harmony at school is the tradition of celebrating religious holidays held at school, such as Eid al-Fitr or Eid al-Adha, Christmas, and Chinese New Year. If one of the religious communities celebrates their holiday, the other religions do not only participate but also contribute to celebrating it. For example, when Muslims celebrate Eid at school, other Christian and Buddhist school's residents also help in preparing the event, and they even provide material and assistance such as bringing food or something else. Likewise, if Christian or Buddhism celebrate their holidays at school, then those are Muslims also do the same thing. These activities have become essential activities carried out in the school environment in maintaining harmony among religious communities.

Second, social harmony is a form of cooperation involving all components of religions to carry out social agendas such as helping victims of natural disasters, caring for the environment, and other social humanitarian actions. Social harmony is also values manifestation of religious teachings expressed in real life so that the messages and teachings of religion can be seen and felt along with its benefits. The examples of this social harmony are activities carried out by involving all school members in various social actions such as Islamic, Christian, and Buddhist cooperation in various humanitarian activities such as helping people who experience fire, floods, landslides, assisting orphanages and nursing homes. This action has become a shared spirit 
in framing family ties among school members and has formed a common approach in line with needs.

Third, cultural harmony is cooperation between religious groups through a cultural approach in which culture becomes a meeting point for religions in one context. This approach perceives that culture becomes a bridge that can meet the differences of each religion. The activities reflecting cultural harmony practiced by this school can be seen during the celebration of the Islamic new year or the commemoration of the Prophet $\mathrm{Mu}$ hammad Birthday in Gorontalo community tradition, which are often celebrated through parades around the city of Gorontalo and are usually accompanied by Gorontalo traditional cake pageantry. Although this tradition is an activity for Muslims, Christian and Buddhist students are also involved in the parade activities. The participation or involvement is not based on being forced but based on the desire and agreement of other religions to participate. Collaboration through this approach has a relationship of meaning that the cultural values integrated with religious traditions are not a separator of social-human bonds but rather a source for building social-human values.

The three approaches mentioned above are ways to maximize the variety of different socio-religious potentials and avoid conflicts in the name of religion. Even so, the three approaches above have three points at once, namely dividing points, meeting points, and dispute points. The dividing point lies in different regions of the doctrines, symbols, and rituals carried out by each of these religions (Abdullah 1999, ix), which indeed cannot be imposed or uniformed. If doing so, religion will lose its fundamental value.

The closest meeting point of the three religions is the dimension of humanity because human beings are the ones who determine how religion will become in the future. Humanitari- 
an universalism becomes a meeting point for religions to create justice in maintaining the balance of life. Mahatma Gandhi calls humanity universalism with the phrase "All Man is Brother" that all humans are tied in brotherhood. Abdurrahman then emphasized his form by seeing all human beings are equal before the law, and the implication was that justice could be realized as a shared responsibility.

The point of the dispute between these religions is very complex. The complexity is obvious when religion meets with political and ideological problems in society. The complexity of political interest occurs when it has become an interest and power of one particular group or individual to defend their power. At this stage, the religion does not only mean the teaching itself (theological) but also manifests in particular social systems and structures. In this condition, the point of the dispute will be even stronger because of its practical nature that is prioritizing profits. As a result, this context produces a group of majority and minority, as well as other terms that refer to other forms of power.

The school has implemented multi-approaches, which means that to achieve harmonization between religious groups in a school environment requires a variety of approaches as described previously. The harmonization of Islam, Christianity, and Buddhism in this school is integrated with the "three forms of harmony" approaches, namely the religious, social, and cultural harmony approach. With such approach models, tolerance grows, justice becomes concrete, and the religious and general needs of all school members can be met. Hasan Hanafi argues that peace or harmonization is not just words, but it should be realized in actions. Peace cannot be implemented only by conferences, regular meetings, and protracted negotiations because it is aimed at truth instead of strength (Hanafi 2001, 148). 
Hasan Hanafi's argument above is full of self-criticism toward the forms of religions' harmonization that occurs in various parts of the world today, including in Indonesia. So, the harmonization meant is not clear between how the harmonization should be with the reality that is happening to be very opposite. The social conditions in which political, economic, ideological, and other battles take place make reality more complex and complicated.

What is implemented in this institution has raised interesting facts that what is feared by the general public becomes a capital that strengthens the institution's vision in building harmony among religious communities. The political dimension, which is mostly feared, for example, is used as a potential that strengthens school policies in achieving the goal of harmonizing religious communities, which is realized in the form of cooperation with various religious, social institutions, and the government. This means that the political dimension turns out to be positive when it is placed in the right position, such as building cooperation with institutions or other parties to develop the school visions. Thus, harmonization between religious communities practiced in this school is supported by not only the spirit of the school community but also other forces such as the political dimension used to build cooperation with other institutions.

\section{Method of Harmony Cooperation}

The word method comes from the Greek meta (which means towards, through, or along) and hodos (way), and logos means knowledge. The method then is defined as an effort to specify the steps that must be taken to search for and find knowledge (the way to acquire knowledge) (Zuhri 2016, 89). Anton Bakker, as quoted by Zuhri, concludes that the method refers to a way of acting according to a specific regulatory system with the intention that practical activities carried out are rationally directed in order to achieve optimal results (Zuhri 2016, 89). 
In this context, the method is the path or way taken to achieve harmony between religious communities in both thought and action. By referring to the practice implemented by the school, the harmony method is carried out through two main doors, namely cooperation, and habituation. The cooperation, as meant in previously explanation, refers to the one made by all school members through religious, social and cultural activities, so that it establishes a sense of kinship among all school members and erodes prejudice against each other. The habituation referred here is a whole series of various collaborations for all school residents, which results in harmony collaboration. Harmony is not only in the form of ideas, thoughts, and words, but is also manifested in real practice in the daily lives of all school members. This is the key to the realization of harmonization among all school residents to date. This method is on target because it becomes a habit that is continuously carried out to produce characteristics of school residents based on the practice and experience they live every day at school. The figure 1 illustrates the workings of the harmony method.

Figure 1

Methods of harmony cooperation

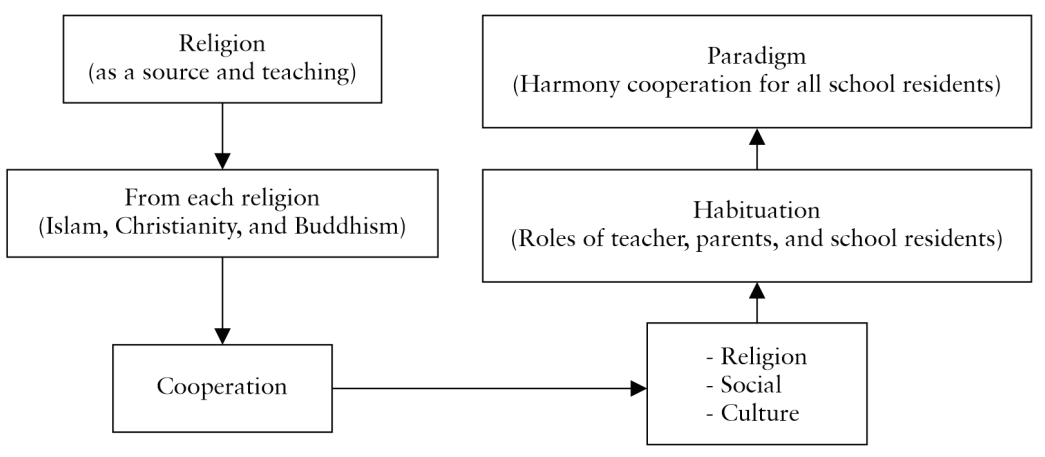

In figure 1, the form of harmonization between religious communities in the school environment does not just happen, 
but through several stages that become links. The source of teaching values developed by the school is the source of each religion teachings. In the Islamic perspective, for example, the school develops the values of the teachings contained in the al-Quran, as stated in al-Quran, al-Hujurat: 13.

It means: "O people, indeed We created you from a man and a woman, and made you tribes and tribes so that you know each other. Surely the most noble of you in the sight of Allah is the most pious among you. Truly Allah is All-Knowing, All-Knowing. (Shihab 2002, 260)

Quraish Shihab argues that the above verse requires human beings to know one another where the stronger one party to recognize the other, the more opportunities will open for mutual benefit. Introductions are needed to mutually attract lessons and experiences in order to increase piety to Allah swt. The impact of this introduction is reflected in the peace and prosperity of worldly life and ukhrawi's happiness. Conversely, when people do not know each other, they cannot draw lessons, cannot complement each other, and cannot give benefit to each other (Shihab 2002).

Meanwhile, Nurcholish Madjid explains that the above verse is related to the principle of religious plurality, how Muslims develop the plurality dimension positively and optimistically, and do good deeds based on reality itself (Madjid 2001, 48). According to Abdurrahman Wahid, pluralism is not just peaceful coexistence, but to recognize and accept the diversity that exists is more substantial (Wahid 1998, 59).

The above explanation emphasizes that Islam has a clear view of religious pluralism, where its purpose is to maintain the balance of human life as God's creations in order to complement each other and provide mutual benefits for human survival. One example of material related to that context is taught at school, for example: 
Udin worships at the mosque, and Edo worships at the church.

Their religion is different, but still respect each other (Kementerian Pendidikan Kebudayaan Republik Indonesia, 92).

From the perspective of Christianity, what is taught by the school about interfaith relations is developed from Christian teachings that originate in the Bible such as the "Law of Love" which explains to love human beings, such as loving oneself (Silabus Pendidikan Agama Kristen dan Budi Pekerti 2016-2017, 13). The teaching values are practiced daily, for example, how students do not pick and choose friends for mingling, having mutual respect for differences, and conducting cooperation and help each other.

While in the Buddhist perspective, students are taught material about the nature of God in Buddhism, namely, love (metta), compassion (karuna), sympathy (mudita), and inner balance (upekkha) (Rencana Pelaksanaan Pembelajaran 2016-2017,21). Such material is related to the religious context in the school, which consists of Islam, Christianity, and Buddhism. The teaching guides students on how they get along every day, including doing good to other fellows in any context that should reflect the values taught in Buddhism from speeches to actions.

The teaching materials above become important parts of the spirit of cooperation among religious communities in the school environment. The concrete form is, as explained in the previous section, that the cooperation is integrated into religious, social, and cultural contexts that contribute to the form of harmonization of Islam, Christianity, and Buddhism.

The collaboration generates the habituation, which refers to a perspective and action integrated into the school environment context through the roles of teachers, students' guardians, and all school members. The teachers become not only teachers but also learners who learn from the surroundings or environment. Likewise, both students' guardians and students also learn from 
one another, so the two-way learning context is not only built but also the broader and dynamic learning context. This condition has brought out the paradigm of harmony cooperation, which is realized by all members of the school. This method offers not only a theoretical interpretation but also praxis since it departs from what has been practiced in the field. This method is also dynamic and able to adapt to the context where it will be practiced because the aim is to answer existing social problems, so this method can be an alternative to develop and measure other social contexts.

\section{Conclusion}

This study draws some fundamental conclusions. Firstly, the form of harmonization between Islam, Christianity, and Buddhism that exists in SD Negeri 46 Hulontalangi Gorontalo City takes place because the meeting of the three religions in a school environment, and Pancasila is used as the basis for policy. These conditions are then realized by the cooperation of all school residents who form the habituation value related to religious pluralism for school residents, then build harmony between religious communities.

Secondly, the existence of cooperation in religion, social, and culture becomes the real form of harmonization among religious communities in this school. The example of this harmonization is the cooperation between all school members in celebrating religious holidays, in social and humanitarian action, and cultural matters.

Lastly, the harmonization construction above offers a method called harmony cooperation, which is not only in the form of thoughts and words but also in the form of actions. The method explains that religion is a source to extract teaching values that can answer the context of plurality. The teaching is explored from each religious teaching of Islam, Christianity, and Buddhism, in 
which all of these teachings values are then used to build religious, social, and cultural cooperation. This has become a habit that cannot be separated from the roles of teachers, parents and all school members so that this process forms the paradigm of harmony cooperation.

\section{Bibliography}

Abdullah, M. Amin. 1999. "Relevansi Studi Agama di Era Pluralisme Agama." In Muhammad Sabri. Keberagamaan yang Saling Menyapa: Perspektif Filsafat Perenial. Yogyakarta: Bigraf.

_ 2005. "Perspektif Analitis dalam Studi Keragaman Agama: Mencari Bentuk Baru Metode Studi Agama." In Harmoni Kehidupan Beragama: Problem, Praktik dan Pendidikan, edited by Alef Theria Wasim. Yogyakarta: Oasis Publisher.

Silabus Pendidikan Agama Kristen dan Budi Pekerti 2016-2017 SD Negeri 46 Hulontalangi. 2016. Kota Gorontalo.

Djam'annuri. 2002. Agama Kita: Perspektif Sejarah Agama-Agama (Sebuah Pengantar). Yogyakarta: Kurnia Kalam Semesta Bekerjasama dengan Lembaga Studi Filsafat Islam.

Hanafi, Hasan. 2001. Agama, Kekerasan, dan Islam Kontemporer, (terj.) oleh Ahmad Najib. Yogyakarta: Jendela.

Kementerian Pendidikan Kebudayaan Republik Indonesia. 2013. Buku Tematik Kelas 2 Tema 1, Hidup Rukun. Jakarta: Grafindo.

Madjid, Nurcholish. 2001. Pluralitas Agama: Kerukunan dalam Keragaman. Jakarta: Kompas.

. 2005. Islam, Doktrin dan Perdaban, Sebuab Telaab Kritis tentang Masalah Keimanan, Kemanusiaan dan Kemodernan. Jakarta: Paramadina.

Makin, Al. 2016. “Unearthing Nusantara’s Concept of Religious 
Pluralism; Harmonization and Syncretism in Hindu-Buddhist and Islamic Classical Texts." Journal Al-Jāmi'ah. Vol 54 (2): 28-29.

Mukti, Ali. 1976. Ke-Esa-an Tuhan dalam Al-Qur'an. Yogyakarta: Yayasan Nida.

Rencana Pelaksanaan Pembelajaran. 2016. Pendidikan Agama Budha dan Budi Pekerti, SD Negeri 46 Hulontalangi. Kota Gorontalo.

BPS Gorontalo. 2017. Badan Pusat Statistik (BPS) Provinsi Gorontalo 2016/2017.

Sekolah, Dokumen. 2017. Data Jumlah Peserta Didik SD Negeri 46 Hulontalangi Kota Gorontalo 2017.

Shihab, M.Quraish. 2002. Tafsir al-Misbah: Pesan, Kesan dan Keserasian al-Qur'an, cet. Ke-1. Jakarta: Lentera Hati.

Sugiyono. 2008. Metode Penelitian Pendidikan: Pendekatan Kuantitatif, Kualitatif dan R \& D. Bandung: Alfabeta.

Suseno, Franz Maghnis. 2005. "Kerukunan Beragama dalam Keragaman Agama: Kasus di Indonesia.” In Harmoni Kehidupan Beragama: Problem, Praktik dan Pendidikan, edited by Alef Theria Wasim. Yogyakarta: Oasis Publisher.

Undang-Undang Sistem Pendidikan Nasional 2008 UU RI No. 20 Tahun 2003. n.d. Jakarta: Sinar Grafika.

Wahid, Abdurrahman. 1998. "Dialog Agama dan Masalah Pendangkalan Agama" in Komarudin Hidayat dan Ahmad Gaus AF. Passing Over: Melintas Batas Agama. Jakarta: Gramedia dan Paramadina.

Zuhri, H. 2016. Studi Islam: Sebuah Pengantar. Yogyakarta: FA Press. 
This page intentionally left blank 